\title{
EFFECTS OF HUMIC ACID AND IRON APPLICATIONS ON THE YIELD, SOME PLANT CHARACTERISTICS AND OIL RATIO OF SAFFLOWER (Carthamus tinctorius L.)
}

\author{
BEYYAVAS, V. - HALILOGLU, H. \\ Department of Field Crops, Faculty of Agriculture, Harran University, Osmanbey Campus, \\ Sanliurfa 63050, Turkey \\ *Corresponding author \\ e-mail: haliloglu@harran.edu.tr; phone: +90-530-205-0794 \\ (Received 10 $0^{\text {th }}$ Aug 2020; accepted $19^{\text {th }}$ Nov 2020)
}

\begin{abstract}
This study was conducted to determine the effects of humic acid and iron applications on seed yield, some plant characteristics and oil ratio of Remzibey-05 safflower cultivar under Harran Plain conditions in the 2011-2012 and 2012-2013 growing seasons. The experiment was carried out in randomized complete block split plots design with three replications. The main plots were humic acid (HA) applications $\left(0,60 \mathrm{~g} \mathrm{ha}^{-1}, 120 \mathrm{~g} \mathrm{ha}^{-1}, 180 \mathrm{~g} \mathrm{ha}^{-1}\right)$, and the sub-plots were iron (Fe) applications $(0$, $12.5 \mathrm{~kg} \mathrm{ha}^{-1}, 25 \mathrm{~kg} \mathrm{ha}^{-1}$ and $37.5 \mathrm{~kg} \mathrm{ha}^{-1}$ ). Humic acid was sprayed onto the leaves and iron was applied to the soil when the plants were leading the stage of 4-5 leaves. The highest seed yield, number of heads per plant and dry petal yield per plant were obtained from $120 \mathrm{~g} \mathrm{ha}^{-1}$ humic acid and $12.5 \mathrm{~kg} \mathrm{ha}^{-1} \mathrm{Fe}$ applications. The highest number of seeds per head was obtained from $180 \mathrm{~g} \mathrm{ha}^{-1} \mathrm{HA}$ and $12.5 \mathrm{~kg} \mathrm{ha}^{-1} \mathrm{Fe}$ applications while biomass yield was from $60 \mathrm{~g} \mathrm{ha}^{-1} \mathrm{HA}$ and $25 \mathrm{~kg} \mathrm{ha}^{-1} \mathrm{Fe}$ applications. In conclusion; $120 \mathrm{~g} \mathrm{ha}^{-1}$ humic acid and $12.5 \mathrm{~kg} \mathrm{ha}^{-1}$ Fe should be applied to increase seed yield, number of heads per plant and dry petal yield per plant in safflower agriculture under semi-arid climate conditions.
\end{abstract}

Keywords: semi-arid, carthamus, spiny, hoeing, dry petal

\section{Introduction and literature review}

Safflower is a multipurpose oil seed crop that can be used for cooking as vegetable oil, cut flower, forage crop for both forage and animal feeding, industrial crop for dye production and medicinal crop. Safflower is tolerant to drought, heat, cold and saline conditions (Emongor and Oagile, 2017). It is well adapted to dry regions and easy to cultivate. It is extremely effective in reaching moisture and nutrients that are difficult to obtain and are otherwise in limited supply due to the its taproot. This contributes to the improvement to the structure of soil, including the formation of organic matter and the improvement of soil structure and the promotion of water leakage. These features make safflower plant an excellent rotation crop in many regions (Anonymous, 2016).

Safflower is an annual herbaceous plant which is grown commercially to obtain vegetable oil. It was initially cultivated to get dye from its flowers. It was traditionally grown for its seeds and also used for dyeing of fabrics with some foodstuffs. Red and yellow dyes are obtained from safflower. Extracts of the plant are also used to make medicines. Oil has been commercially extracted from safflower seeds in recent years (Anonymous, 2019).

Dried petals are used to extract natural dyes from plants that are important nowadays due to their natural contents and fashion trends. The colored material in safflower is Carthamine that based on benzoquinone (Garcia, 2009). Flavonoid type dye exists in safflower plant. Cotton, wool and other hydrophilic fibers can be colored directly with safflower dye (Badiger et al., 2009). The water-soluble yellow dye (carthamidin) and 
the insoluble red dye (carthamine) are used in the carpert-weaving industry in Eastern Europe and Indian subcontinent (Weiss, 1983).

Safflower plants have yellow, orange or red flowers, height between 30 and $210 \mathrm{~cm}$ and roots that can go down to 2-3 m (Emongor and Oagile, 2017). Each branch of the plant produces 1 to 5 heads and 15 to 20 seeds per head. Seed oil ratio is between 25-45 and $90 \%$ of this oil is oleic and linoleic acid (Baydar and Erbas, 2016). Safflower oils containing high percentage of linoleic acid are used in the production of paints, varnishes, printing inks, protective acrylic resins and soap industry with their excellent drying properties (Corleto et al., 1997).

The remaining cake after safflower oil was extracted is a good feed source in animal husbandry with a content of up to $25 \%$ crude protein (Weiss, 2000). In addition, safflower seeds are used as bird feed. The importance of safflower seed as oilseed product has increased in recent years especially with the increasing interest in biofuel production (Lakzayi and Sabbagh, 2015; Hussain et al., 2015). Safflower production in the world is about 718.161 tons. The countries producing the most safflower is Kazakhistan (174.900 tons), India (109.000 tons) and USA (95.360 tons). Turkey is an important country at the sixth rank with 45.000 tons (Anonymous, 2019). The growth and effectiveness of the safflower (Carthamus tinctorius L.) plant is affected by genotype, environment and agricultural practices (Koutroubas et al., 2009).

Growth, development and yield of the plant are under the influence of biotic and abiotic conditions that make up the environmental factors together with the genetic potential of the plant (Kaleem et al., 2010). Fertilization, which is one of the abiotic conditions, is one of the factors that have a significant effect on yield and yield components. For years, it has been tried to increase the yield in agricultural areas with inorganic fertilizer applications. However, it has long been overlooked that organic matter is needed in the soil for these fertilizers to be effective.

The most economical and rapid solutions to the organic matter problem is to apply humic or fulvic acid directly to soil or plant. As a plant biostimulants, humic and fulvic acids are produced mainly by biological degradation of plant organic matter containing lignin (Malan, 2015). The favorable effects of organic regulators or plant biostimulants based on humic substances are an alternative method for production and protection of soil fertility (Canellas et al., 2015).

Humic acids remain in the soil for a long time and decompose gradually over time. With the application of humic acid, the aeration of the soil and water retention, the development and proliferation of soil microorganisms are provided, the resistance of plants to stress conditions, diseases and pests are increased (Icel, 2005). Humic acid applications are effective on seed yield, oil and protein ratio along with plant characteristics; iron applications are effective on oil yield, seed quality and resistance to drought conditions; in humic x Fe form interaction, especially Fe-EDDHA with humic acid application was reported positive effects on plant development, microelements level and other properties (Korkmaz, 2000). It was reported that fulvic acid $\left(1 \mathrm{~kg} \mathrm{ha}^{-1}\right)$ application on the leaves increased seed yield by $6.02 \%$ and oil yield by $85.67 \%$ (Moradi et al., 2017).

Iron by biosynthetic ways is required in a few steps. However, iron deficiency can restrain cell number and its size, cell cleavage, leaf growth, and contents of chlorophyll, protein, starch and sugar. Consequently, reduce the plant's fresh and dry weights (Marschner, 1995). Iron (Fe) is a cofactor for approximately 140 enzymes that catalyze 


$$
\text { - } 309 \text { - }
$$

unique biochemical reactions (Brittenham, 1994). The stimulatory effect of zinc and/or iron was recorded by Pande et al. (2007) and Said-Al et al. (2009).

Safflower has a great potential for dry farmland of southeastern region of Turkey in dry years due to obtaining satisfy yield and high revenue of by-products. Especially the petals used as food color and spices have the potential to increase the income of farmers in arid agricultural areas (Esendal, 2001). However, depending on the climatic conditions and varieties, seed yields vary according to regions.

This study was conducted to determine the effects of humic acid and iron doses on seed yield and some plant characteristics of safflower plant and to help in future studies.

\section{Materials and methods}

\section{Fields studies}

This trial was carried out in a randomized complete split plots design with three replications at Eyyubiye campus experimental area, Agricultural Faculty, Harran University ( $\left.37^{\circ} 07^{\prime} 12^{\prime \prime} \mathrm{N} 38^{\circ} 49^{\prime} 14.91 " \mathrm{E}\right)$ (altitude $=510 \mathrm{~m}$ from sea level) during 2011-2012 and 2012-2013 growing seasons in the Sanliurfa, Turkey (Figures 1 and 2).

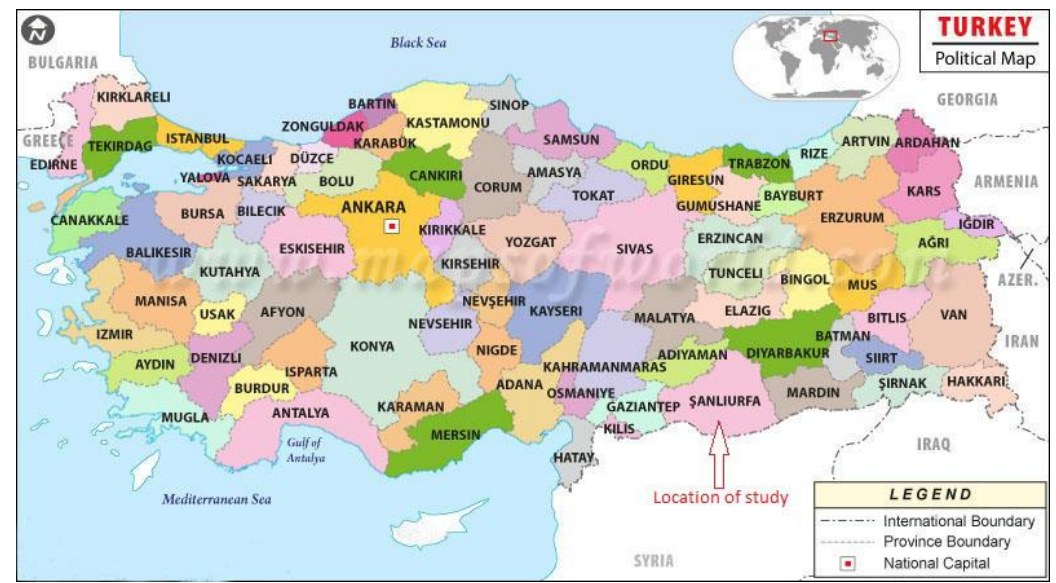

Figure 1. The political map of the Turkey

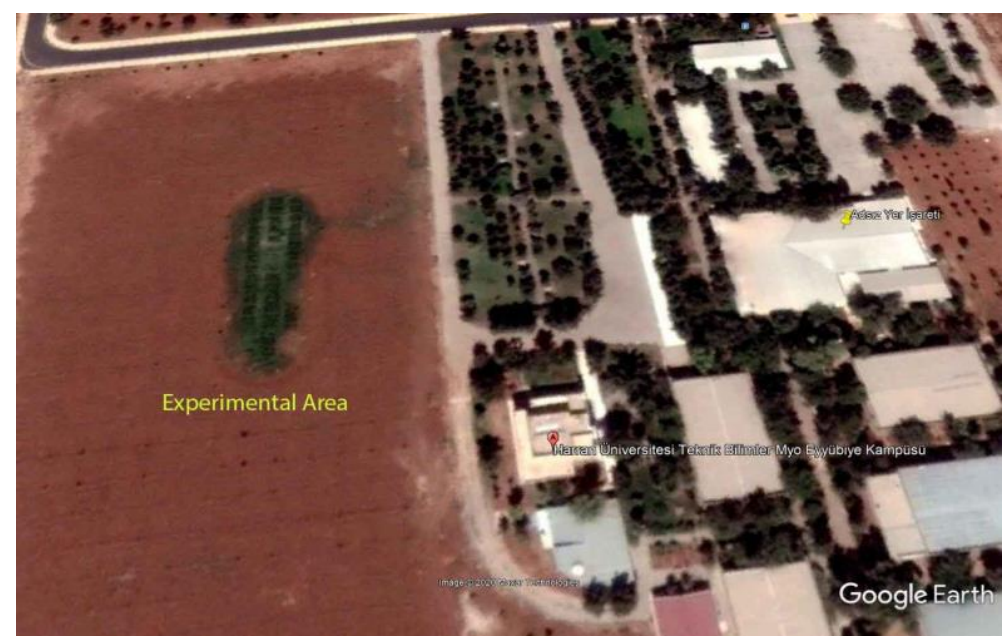

Figure 2. The map of the experimental area 
Variety recommended for the region, Remzibey-05 (spiny) cultivar with yellow flower and head was used as plant material. Experimental area had been ploughed, herbicide (Trifluarin active ingredient) was applied by a sprayer before sowing. Then, disc-harrow was practiced for seedbed prepation. The seeds were sown by the experimental driller on $5^{\text {th }}$ November, 2011 and $3^{\text {th }}$ November, $2012.2 \mathrm{~m}$ space was left between each plot.

Each plot consisted of 6 rows with $5 \mathrm{~m}$ long. Inter-row and intra-row spaces were 35 and $15 \mathrm{~cm}$ respectively. $100 \mathrm{~kg} \mathrm{ha}^{-1}$ of pure $\mathrm{N}$ and $80 \mathrm{~kg} \mathrm{ha}^{-1}$ of pure $\mathrm{P}_{2} \mathrm{O}_{5}$ phosphorus fertilizer were applied. Half of the nitrogen (20.20.0) was applied as basal fertilizer and the remaining half (Ammonium Nitrate 33\%) was applied as top fertilizer at the branching period.

Humic acid doses formed the main plots (HA 0 : Control, $\mathrm{HA}_{1}: 60 \mathrm{~g} \mathrm{ha}^{-1}$, $\mathrm{HA}_{2}: 120 \mathrm{~g} \mathrm{ha}^{-1}$ and $\left.\mathrm{HA}_{3}: 180 \mathrm{~g} \mathrm{ha}^{-1}\right)$. Thinning was practiced in the stages of 3 or 4 leaves. In the period when the plants were 4-5 leaves, humic acid which is in the commercial name "Delta plus +15 ', whose active ingredient is $150 \mathrm{~g} / \mathrm{L}$ humic acid +30 $\mathrm{g} / \mathrm{L}$ potassium oxide, was applied to the leaves at once. Iron doses formed the sub-plots ( $\mathrm{Fe}_{0}$ : Control, $\mathrm{Fe}_{1}$ : $12.5 \mathrm{~kg} \mathrm{ha}^{-1}, \mathrm{Fe}_{2}: 25 \mathrm{~kg} \mathrm{ha}^{-1}$ and $\mathrm{Fe}_{3}: 37.5 \mathrm{~kg} \mathrm{ha}^{-1}$ ) and which is in the commercial name "Ferri Iron Sulphate $\left(\mathrm{Fe}_{2}\left(\mathrm{SO}_{4}\right) 4 \mathrm{H}_{2} \mathrm{O}\right)$ " containing $23 \%$ iron was applied 5-6 $\mathrm{cm}$ next to the rows of the plant and 5-6 $\mathrm{cm}$ in depth by hand.

In the trial area shown in Figure 3, hoeing, weed and pest control were practised conventionally and harvests were done on 7 June in 2012, 8 June in 2013. $0.5 \mathrm{~m}$ of sides effect were discarded at the beginning and end of the 2 rows in the middle of each plot, and the seed and biomass yield $\left(\mathrm{kg} \mathrm{ha}^{-1}\right)$ were determined by hand over the remaining area $\left(4 \mathrm{~m} \mathrm{x} 0.7 \mathrm{~m}=2.8 \mathrm{~m}^{2}\right)$. Plant height $(\mathrm{cm})$, number of heads per plant, number of seeds per head, 1000 seed weight $(\mathrm{g})$ and dry petal yield $\left(\mathrm{g} \mathrm{plant}^{-1}\right)$ were determined on randomly selected and cutted 10 plants at the ground level (Esendal et al., 1992).

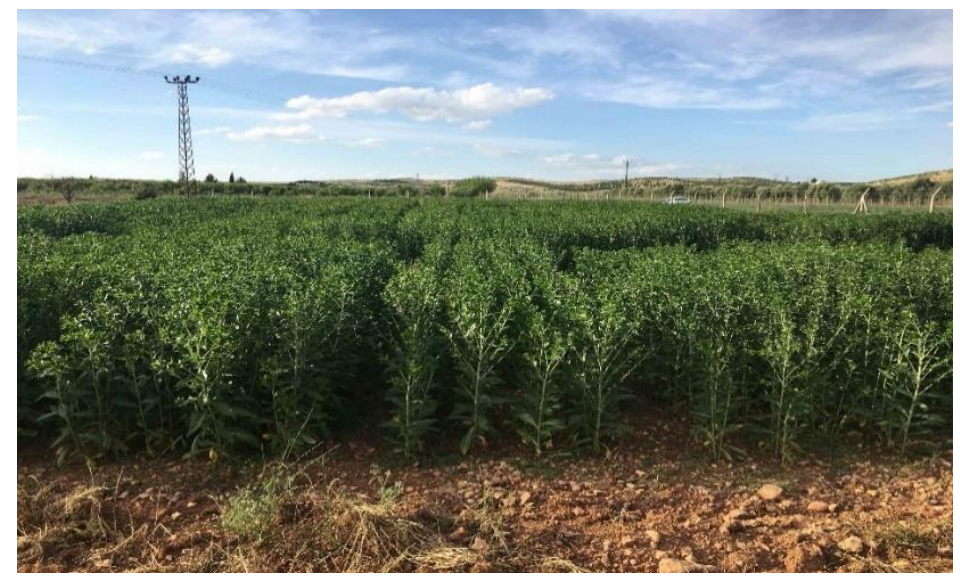

Figure 3. Experimental area

\section{Soil analysis}

The trial area possesses a low slope topography. The physical and chemical properties of the soil were specified before sowing. Trial area has good drainage, deep profile and stone-free. Clay ratio, salt content, $\mathrm{pH}$ degree and organic matter level were designated as $53 \%, 0.090 \%, 7.5$, and $1.21 \%$, respectively. In addition, the amount of pure $\mathrm{N}$ of $23 \mathrm{~kg} \mathrm{ha}^{-1}, \mathrm{P}_{2} \mathrm{O}_{5}$ of $31 \mathrm{~kg} \mathrm{ha}^{-1}$ and $\mathrm{K}_{2} \mathrm{O}$ of $1106 \mathrm{~kg} \mathrm{ha}^{-1}$ were determined (Anonymous, 2011). 


$$
\text { - } 311 \text { - }
$$

\section{Oil ratio}

For each application $10 \mathrm{~g}$ of seeds were grounded and dried in an oven at $70{ }^{\circ} \mathrm{C}$ for 72 hours. $5 \mathrm{~g}$ of each dried sample was taken and boiled for 6 hours using n-hexane in the Soxhlet device and oil ratios (\%) were determined (Bilsborrow et al., 1993).

\section{Meteorological data}

Meteorological datas were taken from the meteorology station, located approximately $3 \mathrm{~km}$ from the area where the research was established.

The amount of rainfall close to each other in both years. The average temperature was near to the average of long years $\left(13.68{ }^{\circ} \mathrm{C}\right)$ in the $2011-2012\left(13.76{ }^{\circ} \mathrm{C}\right)$, but the average temperature was observed higher than first year and long years in the 2012$2013\left(15.31^{\circ} \mathrm{C}\right)$ (Table 1). In the second year of the experiment, the average temperature and especially the higher amount of rainfall in May may have encouraged the plants to develop better.

Table 1. Meteorological data from trial seasons and average of long years

\begin{tabular}{|c|c|c|c|c|c|c|c|}
\hline & \multicolumn{3}{|c|}{ 2011-2012 } & \multicolumn{3}{|c|}{ 2012-2013 } & \multirow{2}{*}{$\begin{array}{l}1929-2013 \\
\text { Average of } \\
\text { Long-term } \\
\left({ }^{\circ} \mathrm{C}\right)\end{array}$} \\
\hline Months & \begin{tabular}{c|} 
Average \\
Monthly \\
Temp. \\
$\left({ }^{\circ} \mathrm{C}\right)$ \\
\end{tabular} & $\begin{array}{c}\text { Precipitation } \\
\quad\left(\mathrm{kg} \mathrm{m}^{-2}\right)\end{array}$ & $\begin{array}{c}\text { Average } \\
\text { Relative } \\
\text { Humidity } \\
(\%)\end{array}$ & $\begin{array}{c}\text { Average } \\
\text { Monthly } \\
\text { Temp. } \\
\left({ }^{\circ} \mathrm{C}\right)\end{array}$ & $\begin{array}{l}\text { Precipitation } \\
\qquad\left(\mathrm{kg} \mathrm{m}^{-2}\right)\end{array}$ & \begin{tabular}{|c|} 
Average \\
Relative \\
Humidity \\
$(\%)$
\end{tabular} & \\
\hline November & 9.4 & 62.1 & 53.7 & 14.9 & 68.4 & 65.6 & 12.9 \\
\hline December & 7.4 & 47.1 & 57.4 & 8.3 & 142.8 & 73.0 & 7.5 \\
\hline January & 5.5 & 170.9 & 81.0 & 6.8 & 86.8 & 69.5 & 5.4 \\
\hline February & 5.8 & 95.8 & 57.0 & 9.3 & 107.2 & 73.6 & 6.8 \\
\hline March & 9.7 & 35.8 & 47.3 & 12.9 & 12.1 & - & 10.7 \\
\hline April & 19.3 & 23.3 & 42.4 & 18.4 & 18.0 & 44.9 & 16.0 \\
\hline May & 22.4 & 42.3 & 40.8 & 22.9 & 56.2 & 43.4 & 22.1 \\
\hline June & 30.6 & 5.8 & 21.2 & 29.0 & - & 24.0 & 28.0 \\
\hline Average & 13.76 & & 50.1 & 15.31 & & 49.25 & 13.68 \\
\hline Total & & 483.1 & & & 491.5 & & \\
\hline
\end{tabular}

Anonymous, 2013

\section{Statistical analysis}

Data were analyzed in the statistical program of JMP 13.2.0 (SAS institute) according to randomized blocks design of humic acid and iron applications, and humic acid $\mathrm{x}$ iron interactions were analyzed according to randomized blocks split plots design. The means were grouped according to Tukey-HSD Multiple Comparison Test $(\mathrm{P}=0.05)$. Relationship between each parameter was determined by Pearson correlation analysis.

\section{Results and discussion}

As a result of the combined years analysis (ANOVA), there was a statistically significant difference between the years in terms of characteristics examined, and the data of each year were analyzed separately (Tables 2 and 3). 


$$
\text { - } 312 \text { - }
$$

Table 2. Data of seed yield $\left(\mathrm{kg} \mathrm{ha}^{-1}\right)$, plant height $(\mathrm{cm})$, number of heads per plant and number of seeds per head examined during the trial years

\begin{tabular}{|c|c|c|c|c|c|c|c|c|}
\hline & \multicolumn{2}{|c|}{$\begin{array}{c}\text { Seed Yield } \\
\left(\mathrm{kg} \mathrm{ha}^{-1}\right)\end{array}$} & \multicolumn{2}{|c|}{$\begin{array}{c}\begin{array}{c}\text { Plant Height } \\
(\mathrm{cm})\end{array} \\
\end{array}$} & \multicolumn{2}{|c|}{$\begin{array}{c}\text { Number of heads } \\
\text { per plant }\end{array}$} & \multicolumn{2}{|c|}{$\begin{array}{c}\begin{array}{c}\text { Number of seeds } \\
\text { per head }\end{array} \\
\end{array}$} \\
\hline & 2011-12 & 2012-13 & 2011-12 & 2012-13 & 2011-12 & 2012-13 & 2011-12 & 2012-13 \\
\hline $\mathrm{HA}_{0}$ & $836.1^{\mathrm{c}^{\phi}}$ & $1549.8^{c^{\phi}}$ & $131.90^{\mathrm{ns}}$ & $137.23^{\mathrm{b}^{\phi}}$ & $10.50^{\mathrm{b}^{\phi}}$ & $16.97^{\mathrm{b}^{\phi}}$ & $12.41^{\mathrm{b}^{\phi}}$ & $10.17^{\mathrm{b}^{\phi}}$ \\
\hline $\mathrm{HA}_{1}$ & $1104.5^{b}$ & $1334.1^{\mathrm{d}}$ & 127.83 & $140.63^{\mathrm{a}}$ & $13.10^{\mathrm{a}}$ & $14.97^{\mathrm{c}}$ & $14.67^{\mathrm{a}}$ & $5.92^{\mathrm{d}}$ \\
\hline $\mathrm{HA}_{2}$ & $1192.6^{a}$ & $1946.7^{\mathrm{a}}$ & 128.70 & $139.23^{a b}$ & $13.00^{\mathrm{a}}$ & $21.50^{\mathrm{a}}$ & $12.81^{b}$ & $7.46^{c}$ \\
\hline $\mathrm{HA}_{3}$ & $1062.6^{b}$ & $1695.7^{\mathrm{b}}$ & 127.83 & $141.03^{\mathrm{a}}$ & $12.23^{\mathrm{a}}$ & $16.73^{b}$ & $15.80^{\mathrm{a}}$ & $12.01^{\mathrm{a}}$ \\
\hline $\mathrm{CV} \%$ & 2.30 & 1.67 & 1.41 & 8.39 & 2.92 & 3.26 & 3.42 & 1.55 \\
\hline $\mathrm{Fe}_{0}$ & $836.1^{\mathrm{d}^{\phi}}$ & $1549.8^{b^{\phi}}$ & $131.90^{\mathrm{ns}}$ & $137.23^{\mathrm{c}^{\phi}}$ & $13.60^{b^{\phi}}$ & $16.97^{b^{\phi}}$ & $12.91^{\mathrm{b}^{\phi}}$ & $10.17^{\mathrm{c}^{\phi}}$ \\
\hline $\mathrm{Fe}_{1}$ & $1353.3^{\mathrm{a}}$ & $2040.7^{\mathrm{a}}$ & 131.83 & $140.43^{\mathrm{ab}}$ & $16.13^{\mathrm{a}}$ & $18.80^{\mathrm{a}}$ & $15.80^{\mathrm{a}}$ & $17.30^{\mathrm{a}}$ \\
\hline $\mathrm{Fe}_{2}$ & $1086.4^{b}$ & $1534.4^{b}$ & 129.87 & $139.90^{b c}$ & $12.77^{b}$ & $18.93^{\mathrm{a}}$ & $15.60^{\mathrm{a}}$ & $10.86^{c}$ \\
\hline $\mathrm{Fe}_{3}$ & $919.1^{\mathrm{c}}$ & $1467.2^{\mathrm{b}}$ & 129.23 & $143.23^{\mathrm{a}}$ & $10.50^{\mathrm{c}}$ & $18.70^{\mathrm{a}}$ & $14.02^{b}$ & $14.84^{b}$ \\
\hline $\mathrm{CV} \%$ & 1.97 & 1.77 & 2.18 & 0.71 & 3.06 & 2.31 & 3.41 & 2.75 \\
\hline Interactions & \multicolumn{8}{|c|}{ F Values } \\
\hline \begin{tabular}{l|}
$\mathrm{HA}$ \\
\end{tabular} & $119.03 * *$ & $268.08 * *$ & $3.39^{\mathrm{ns}}$ & $6.46 *$ & $34.05 * *$ & $70.97 * *$ & $33.37 * *$ & $1172.78 * *$ \\
\hline $\mathrm{Fe}$ & $366.57 * *$ & $243.84 * *$ & $0.69^{\mathrm{ns}}$ & $18.25 * *$ & $98.54 * *$ & $14.35 * *$ & $22.82 * *$ & $254.50 * *$ \\
\hline $\mathrm{HA} \times \mathrm{Fe}$ & $78.90 * *$ & $77.63 * *$ & $5.87 * *$ & $9.59 * *$ & $78.26 * *$ & $62.53 * *$ & $18.05 * *$ & $38.05 * *$ \\
\hline
\end{tabular}

Abbreviations used in the table: "Means that do not share a letter are significantly different, *: $(p \leq 0.05)$, **: ( $\mathrm{p} \leq 0.01)$, ns: non-significant, HA: Humic Acid, Fe: Iron, CV: Coefficient of variations

Table 3. Data of 1000 seed weight ( $g$ ), oil ratio (\%), dry petal yield per plant $(\mathrm{g})$ and biomass yield $\mathrm{kg} \mathrm{ha}^{-1}$ ) examined in the trial years

\begin{tabular}{|c|c|c|c|c|c|c|c|c|}
\hline & \multicolumn{2}{|c|}{$\begin{array}{l}1000 \text { Seed Weight } \\
(\mathrm{g})\end{array}$} & \multicolumn{2}{|c|}{$\begin{array}{c}\text { Oil Ratio } \\
(\%)\end{array}$} & \multicolumn{2}{|c|}{$\begin{array}{c}\text { Dry Petal Yield } \\
\text { Per Plant (g) }\end{array}$} & \multicolumn{2}{|c|}{$\begin{array}{c}\text { Biomass Yield } \\
\left(\mathrm{kg} \mathrm{ha}^{-1}\right)\end{array}$} \\
\hline & 2011-12 & 2012-13 & 2011-12 & 2012-13 & 2011-12 & 2012-13 & 2011-12 & 2012-13 \\
\hline $\mathrm{HA}_{0}$ & $28.03^{\mathrm{ns}}$ & $28.46^{\mathrm{ns}}$ & $30.07^{\mathrm{ns}}$ & $30.27^{\mathrm{ns}}$ & $0.81^{\mathrm{c}^{\phi}}$ & $1.04^{\mathrm{d}^{\phi}}$ & $5500.0^{a^{a^{\phi}}}$ & $7686.7^{b^{\phi}}$ \\
\hline $\mathrm{HA}_{1}$ & 29.40 & 27.92 & 29.67 & 30.27 & $0.95^{\mathrm{ab}}$ & $1.25^{\mathrm{c}}$ & $5666.7^{\mathrm{a}}$ & $9333.3^{\mathrm{a}}$ \\
\hline $\mathrm{HA}_{2}$ & 28.47 & 28.62 & 30.20 & 30.80 & $1.05^{\mathrm{a}}$ & $1.73^{\mathrm{a}}$ & $5200.0^{b c}$ & $7570.0^{b}$ \\
\hline $\mathrm{HA}_{3}$ & 28.65 & 28.70 & 29.27 & 30.13 & $0.92^{b c}$ & $1.46^{\mathrm{b}}$ & $5066.7^{\mathrm{c}}$ & $7980.0^{b}$ \\
\hline $\mathrm{CV} \%$ & 1.96 & 2.66 & 1.64 & 1.80 & 4.51 & 1.46 & 2.04 & 4.40 \\
\hline $\mathrm{Fe}_{0}$ & $27.17^{c^{\phi}}$ & $28.46^{\mathrm{ns}}$ & $30.07^{\mathrm{ns}}$ & $30.27^{a b^{\phi}}$ & $0.81^{b^{\phi}}$ & $1.04^{\mathrm{d}^{\phi}}$ & $5500.0^{\mathrm{d}^{\phi}}$ & $7686.7^{b^{\phi}}$ \\
\hline $\mathrm{Fe}_{1}$ & $28.13^{b}$ & 30.22 & 30.33 & $31.73^{\mathrm{a}}$ & $1.12^{\mathrm{a}}$ & $1.15^{\mathrm{c}}$ & $6033.3^{c}$ & $9010.0^{\mathrm{a}}$ \\
\hline $\mathrm{Fe}_{2}$ & $29.87^{a}$ & 30.76 & 30.54 & $30.60^{a b}$ & $0.84^{b}$ & $1.82^{\mathrm{a}}$ & $6933.3^{\mathrm{a}}$ & $8606.7^{\mathrm{a}}$ \\
\hline $\mathrm{Fe}_{3}$ & $28.03^{b}$ & 31.05 & 29.73 & $29.80^{b}$ & $0.82^{b}$ & $1.43^{\mathrm{b}}$ & $6500.0^{b}$ & $8966.7^{a}$ \\
\hline $\mathrm{CV} \%$ & 0.82 & 3.25 & 1.57 & 1.77 & 3.77 & 1.74 & 2.09 & 2.83 \\
\hline Interactions & \multicolumn{8}{|c|}{ F Values } \\
\hline HA & $3.11^{\mathrm{ns}}$ & $0.64^{\mathrm{ns}}$ & $2.22^{\mathrm{ns}}$ & $0.88^{\mathrm{ns}}$ & $17.04 * *$ & $643.28 * *$ & $18.86 * *$ & $15.43 * *$ \\
\hline $\mathrm{Fe}$ & $70.49 * *$ & $4.21^{\mathrm{ns}}$ & $1.63^{\mathrm{ns}}$ & $6.97 *$ & $58.57 * *$ & $654.16 * *$ & $67.20 * *$ & $19.21 * *$ \\
\hline $\mathrm{HA} \times \mathrm{Fe}$ & $13.57 * *$ & $3.32 * *$ & $3.84 * *$ & $3.17 *$ & $8.50 * *$ & $658.56 * *$ & $33.18 * *$ & $4.88 * *$ \\
\hline
\end{tabular}

Abbreviations used in the table: ${ }^{\phi}$ Means that do not share a letter are significantly different, *: $(\mathrm{p} \leq 0.05)$, **: $(\mathrm{p} \leq 0.01)$, ns: non-significant, HA: Humic Acid, Fe: Iron, CV: Coefficient of variations 


\section{Seed yield $\left(\mathrm{kg} \mathrm{ha}^{-1}\right)$}

In both years of the experiment, $\mathrm{H}_{2}\left(1192.6 \mathrm{~kg} \mathrm{ha}^{-1}\right.$ and $\left.1946.7 \mathrm{~kg} \mathrm{ha}^{-1}\right)$ application in terms of humic acid application, $\mathrm{Fe}_{1}\left(1353.3 \mathrm{~kg} \mathrm{ha}^{-1}\right.$ and $\left.2040.7 \mathrm{~kg} \mathrm{ha}^{-1}\right)$ application in terms of iron application gave the highest seed yield. There were statistically significant $(\mathrm{p} \leq 0.01)$ differences between humic acid, iron and HA x Fe interactions (Table 2). This showed that both humic acid and iron applications were important to increase seed yield of safflower.

Resulting that $120 \mathrm{~g} \mathrm{ha}^{-1}$ was recommended for humic acid applications and $12.5 \mathrm{~kg} \mathrm{ha}^{-1}$ for iron applications. Vaughan and Linehan (1976) postulated that the effect of humic acid on plant growth can be made directly by the use of iron exchanged, and indirect effects of these hormones by the end of increased of microbial activity while Lobartini et al. (1997) reported that soil humic substances increase the fertility of the soil by directly stimulating the metabolic and physiological events in plants and indirectly affecting the physical, chemical and biological properties of the soil.

Moreover, a reliable environment can be created by the use of humic acid that providing the structural development of soils regarding plant production and more environmentally efficient soil (Yilmaz and Alagoz, 2001). Fe element increases of plant photosynthesis and roots growth that lead to net photosynthesis and improved seed yield (Lewis and McFarlane, 1986). Similar results suggested by Movahhedy-Dehnavy et al. (2009), Moradi et al. (2017) and Ekin (2020) that humic acid applications increase seed yield of safflower.

The higher yield in the second year of the research may have been seen due to the amount of rainfall in different growth stages of the plants. When table 1 is examined, the plant growth was better and vegetatively more strong in the second year, as a result of the more rainfall in November and December compared to the first year, and more rainfall in May compared to the first year caused larger and round grains.

\section{Plant height (cm)}

Plant height varied from 127.83 to $143.03 \mathrm{~cm}$ in both experiment years. In the first year of the experiment, there was no statistically significant difference between humic acid and iron applications. In the second year of the experiment, there were statistically significant differences between humic acid $(p \leq 0.05)$ and iron doses $(p \leq 0.01)$, and there were significant differences between $\mathrm{HAxFe}$ interactions $(\mathrm{p} \leq 0.01)$ in both years (Table 2).

However, in the second year $\mathrm{HA}_{1}(140.63 \mathrm{~cm})$ and $\mathrm{HA}_{3}(141.03 \mathrm{~cm})$ applications and $\mathrm{Fe}_{3}(143.23 \mathrm{~cm})$ applications resulted the highest plant height values as reported by Gursoy et al. (2017) and Sahan (2019).

\section{Number of heads per plant}

The most important selection criterion that determines seed yield for safflower plant is the number of heads per plant. In modern safflower varieties, well-developed 12-14 heads are sufficient (Weiss, 2000). Although it is highly affected by environmental conditions (especially sowing density), it is one of the defining characteristics of high yielding safflower varieties. Biological, physical and chemical properties of the soil are affected positively by humic acid application. Fe is a basic element for plant growth, chlorophyll production disorders can be seen in the deficient of Fe. First symptoms of 
Fe chlorosis appear in young tissues due to its substitution within the plant body (Rashno et al., 2013).

Statistically significant differences were obtained between humic acid, iron and $\mathrm{HAxFe}$ interactions in terms of number of heads per plant during the experiment years. The highest number of heads per plant was obtained from $\mathrm{HA}_{2}$ (13.00 and 25.00 per plant) and $\mathrm{Fe}_{1}$ (16.13 and 18.80 per plant) applications in both years. According to the two-year results, $120 \mathrm{~g} \mathrm{ha}^{-1}$ humic acid and $12.5 \mathrm{~kg} \mathrm{ha}^{-1} \mathrm{Fe}$ applications yielded the highest number of heads per plant.

This situation revealed that humic acid and iron applications had significant effects on the number of heads per plant. $120 \mathrm{~g} \mathrm{ha}^{-1}$ humic acid and $12.5 \mathrm{~kg} \mathrm{ha}^{-1}$ iron may be recommended for safflower farming to increase number of heads per plant. Karimi et al. (2016), Mehraban and Miri (2017) reported that the application of humic acid increases the number of heads. Rahimi et al. (2016) indicated that humic acid applications has positive effect on heads per plant therefore the seed number increased. In other word, using humic acid appropriate levels provide better nutrient and water uptake and plant photosynthesis through improving roots expansion development.

\section{Number of seeds per head}

Number of seeds per head is an important yield criterion as the number of heads per plant. The number of seeds per head is directly related to the size of the head. Although an average of approximately 100 flowers occur on the safflower head, $20 \%$ of these flowers form seeds on average (Baydar, 2000). In our study, statistically significant differences were found between humic acid, iron and HAxFe interactions in terms of number of seeds per head. $\mathrm{HA}_{1}$ (14.67 per head) and $\mathrm{HA}_{3}$ (15.80 per head) applications in the first year of the experiment, $\mathrm{HA}_{3}$ (12.01 per head) applications in the second year, $\mathrm{Fe}_{1}$ (15.80 and 17.30 per head) application in terms of Fe applications in both years gave the highest number of seeds per head. The fact that humic acid applications gave different results in both years might be affected from the different environmental and climatic factors during the experiment years.

Increasing of yield components might have been observed due to the positive effects of micronutrient applications on activation of photosynthetic enzymes, chlorophyll formation and plant growth and development (Movahhedy-Dehnavy et al., 2009).

Ekin (2020) indicated that the application of humic acid increases the number of seeds per head is consistent with our results.

\section{0 seed weight $(g)$}

Another third important selection criterion that determines seed yield for safflower is 1000 seed weight. Humic acid applications on 1000 seed weight did not have any statistically significant effect in the two years of experiment and iron applications in the first year of experiment. However, statistically significant differences were observed between HAxFe interactions in both years. When evaluated as a whole, it can be said that humic acid and iron applications did not have any effect on 1000 seed weight when given separately but interaction was important when given together.

However, contrary to our findings, Karimi et al. (2016), Mehraban and Miri (2017), Moradi et al. (2017) and Ekin (2020) stated that humic acid applications positively affect 1000 seed weight. Differences between the studies may have resulted from the difference of cultivars and soil-environmental factors. 


$$
\text { - } 315 \text { - }
$$

\section{Oil ratio (\%)}

The most important quality criterion for safflower plant is the oil ratio of the seed. Oil ratio ranged from $29.67 \%$ to $31.73 \%$. Humic acid applications did not have a statistically significant effect on oil ratio in the two years of the experiment and iron applications in the second year. Significant differences were observed between HAxFe interactions in both years.

In general, humic acid and iron applications did not have any effect on oil ratio when given separately, but interaction was important when given together (Table 3). Movahhedy-Dehnavy et al. (2009) stated that Fe applications increased the quality criteria of safflower, and Darinkaboud and Asl (2016), Karimi et al. (2016) stated that humic acid application increased the oil ratio that are incompatible with our results. This difference may be due to differences of experiment locations, variety used and environmental factors.

\section{Biomass yield ( $\left.\mathrm{kg} \mathrm{ha}^{-1}\right)$}

Significant differences were found between humic acid, iron and humic acid $\mathrm{x}$ iron interactions in both years of the experiment. Among the humic acid applications, $\mathrm{HA}_{1}$ application (5666.7 kg ha-1 and $9333.3 \mathrm{~kg} \mathrm{ha}^{-1}$ ) resulted the highest biomass yield for each year. In iron applications, $\mathrm{Fe}_{2}$ application $\left(6933.3 \mathrm{~kg} \mathrm{ha}^{-1}\right.$ and $\left.8606.7 \mathrm{~kg} \mathrm{ha}^{-1}\right)$ was in the first group statistically in both years of the experiment. Mustin (1987) reported that humic acid reduces the transpiration required for the production of unit dry matter by reducing plant water consumption, by changing the cell permeability of the root increase both selectivity and the absorption of minerals and water, and also reported that due to its effect on photosynthesis and carbohydrate metabolism the mineral substance consumption is lessened.

Biomass increased proportionally with fertilizer variant (Burzo et al., 1999; Haghighati, 2010). Micronutrients are critical for plants owing to increase leaf area index and correspondingly light absorption, dry matter accumulation and economic yield (Ravi et al., 2008). Galavi et al. (2012), informed that the application of foliar iron significantly increased the biological yield compared to the control is consistent with our study. Favorable effect of micronutrient elements on biological yield of safflower has been reported by Movahhedy-Dehnavy et al. (2009). Basalma (2015) stated that application of 60 and $120 \mathrm{~g}$ of seed humic acid per $100 \mathrm{~kg}$ have favorable effects on seedling growth and safflower seed germination when applied before sowing. Galavi et al. (2012) stated that foliar iron application increases biological yield by $80 \%$.

\section{Dry petal yield per plant (g)}

Regarding dry petal yield per plant, significant differences were found between humic acid, iron and humic acid $\mathrm{x}$ iron interactions in both years of the experiment. Dry petal yields varied between $0.81 \mathrm{~g}$ and $1.182 \mathrm{~g}$ between applications. Among the humic acid applications, $\mathrm{HA}_{2}$ application (1.05 $\mathrm{g}$ and $1.73 \mathrm{~g}$ ) gave the best results in both years of the experiment. In iron applications, $\mathrm{Fe}_{1}$ application $(1.12 \mathrm{~g})$ in the first year and $\mathrm{Fe}_{2}$ application $(1.82 \mathrm{~g})$ in the second year formed the highest values.

Movahhedy-Dehnavy et al. (2009) indicated that $\mathrm{Fe}$ applications increased the quality criteria of safflower is consistent with our study. 


$$
\text { - } 316 \text { - }
$$

\section{Correlation coefficients between characteristics examined}

When the correlation coefficients of humic acid and iron applications were analyzed according to the combined years analysis; significant and positive relationships were determined between seed yield and number of heads per plant $(0.535 * *), 1000$ seed weight $(0.258 * *)$, oil ratio $(0.289 * *)$, biomass yield $(0.499 * *)$, dry petal yield per plant $(0.700 * *)$; and between plant height and 1000 seed weight $(0.336 * *)$; and between number of heads per plant and 1000 seed weight $(0.269 * *)$, oil ratio $(0.379$ $* *)$, biomass yield $(0.700 * *)$, dry petal yield per plant $(0.607 * *)$; and between 1000 seed weight and biomass yield $(0.249 * *)$, dry petal yield per plant $(0.254 * *)$; and between oil ratio and biomass yield $(0.260 *)$, dry petal yield per plant $(0.333 * *)$; and between biomass yield and dry petal yield per plant $(0.573 * *)$ (Table 4$)$.

Table 4. Correlation coefficients of examined properties

\begin{tabular}{|c|c|c|c|c|c|c|c|c|}
\hline & $\begin{array}{l}\text { Seed } \\
\text { Yield }\end{array}$ & $\begin{array}{l}\text { Plant } \\
\text { Height }\end{array}$ & $\begin{array}{l}\text { Number of } \\
\text { Heads Per } \\
\text { Plant }\end{array}$ & $\begin{array}{l}\text { Number } \\
\text { of Seeds } \\
\text { Per Plant }\end{array}$ & $\begin{array}{l}1000 \\
\text { Seed } \\
\text { Weight }\end{array}$ & $\begin{array}{l}\text { Oil } \\
\text { Ratio }\end{array}$ & $\begin{array}{l}\text { Biomass } \\
\text { Yield }\end{array}$ & $\begin{array}{l}\text { Dry Petal } \\
\text { Yield Per } \\
\text { Plant } \\
\end{array}$ \\
\hline Seed Yield & 1.000 & & & & & & & \\
\hline Plant Height & 0.116 & 1.000 & & & & & & \\
\hline $\begin{array}{l}\text { Number of Head Per } \\
\text { Plant }\end{array}$ & $0.535^{* *}$ & 0.012 & 1.000 & & & & & \\
\hline $\begin{array}{l}\text { Number of Seed Per } \\
\text { Plant }\end{array}$ & $-0.311 * *$ & -0.098 & $-0.881 * *$ & 1.000 & & & & \\
\hline 1000 Seed Weight & $0.258 *$ & $0.336 * *$ & $0.269 * *$ & $-0.250 *$ & 1.000 & & & \\
\hline Oil Ratio & $0.289 * *$ & 0.027 & $0.379 * *$ & $-0.406 * *$ & 0.196 & 1.000 & & \\
\hline Biomas & $0.499 * *$ & -0.055 & $0.700 * *$ & $-0.606 * *$ & $0.249 *$ & $0.260 * *$ & 1.000 & \\
\hline $\begin{array}{l}\text { Dry Petal Yield Per } \\
\text { Plant }\end{array}$ & $0.700 * *$ & 0.144 & $0.607 * *$ & $-0.533 * *$ & $0.254 *$ & $0.333 * *$ & $0.573 * *$ & 1.000 \\
\hline
\end{tabular}

Abbreviations used in the table: $* *: \mathrm{p} \leq 0.01, *: \mathrm{p} \leq 0.05$

Knowledge on the relationship between yield and plant characteristics for safflower plays a key role in the success of breeding studies.

The relationships between seed yield and number of head per plant, 1000 seed weight, oil ratio and dry petal yield per plant should be taken into consideration in the breeding studies, which to be carried out.

\section{Conclusion}

Despite its versatility usage possibilities, safflower has not yet achieved the value it deserves. It is a very important product especially due to the high nutritional value of its dried flower and oil, and usage in pharmacological and medical, industrial, textile, food, animal feeding. For this reason, neglected and underused and high economic value of this plant deserves sufficient scientific studies and promotion should be done.

As a result of this study, the highest seed yield, number of heads, petal flower yield was obtained from $\mathrm{H}_{2}\left(120 \mathrm{~g} \mathrm{ha}^{-1}\right)$ and $\mathrm{Fe}_{1}\left(12.5 \mathrm{~kg} \mathrm{ha}^{-1}\right)$ applications, the number of seeds per head from $\mathrm{H}_{3}\left(180 \mathrm{~g} \mathrm{ha}^{-1}\right)$ and $\mathrm{Fe}_{1}\left(12.5 \mathrm{~kg} \mathrm{ha}^{-1}\right)$ applications, biomass yield from $\mathrm{H}_{1}\left(60 \mathrm{~g} \mathrm{ha}^{-1}\right)$ and $\mathrm{Fe}_{2}\left(25 \mathrm{~kg} \mathrm{ha}^{-1}\right)$ applications. Humic acid treatments had no significant effect on 1000 seed weight and oil ratio. The effect of iron applications varied according to years. 


$$
\text { - } 317 \text { - }
$$

Generally, safflower producers apply little or no humic acid and iron outside of conventional fertilization programs.

Therefore, it was concluded that $120 \mathrm{~g} \mathrm{ha}^{-1}$ of humic acid and $12.5 \mathrm{~kg} \mathrm{ha}^{-1}$ of iron should be applied to increase seed yield, number of tables heads and petal flower yield in safflower cultivation to be carried out under semi-arid climate conditions.

Acknowledgements. This study was financially supported by the Harran University Scientific Research Board (HÜBAK Project No: 0984).

\section{REFERENCES}

[1] Anonymous (2011): GAP Agricultural Research Institute. - Sanliurfa, Turkey.

[2] Anonymous (2013): Meteorological data obtained from Sanliurfa Meteorological Station. - Sanliurfa, Turkey.

[3] Anonymous (2016): A crop profile for safflower production in California. - March 2016.

[4] Anonymous (2019): Uses of Safflower. - https://www.worldatlas.com/articles/world-stop-safflower-producing-countries.html (Date of access: 29.07.2019).

[5] Badiger, P. K., Rudranaik, V., Parameshwarappa, K. G., Patil, M. S. (2009): Genotype x environmental interactions and stability analysis of non-spiny breeding lines in safflower. - Karnataka J. Agric. Sci. 22(5): 978-981.

[6] Basalma, D. (2015): Effects of humic acid on the emergence and seedling growth of safflower varieties (Carthamus tinctorius L.). - Turkish Journal of Agricultural and Natural Sciences 2(2): 152-156.

[7] Baydar, H. (2000): Effects of gibberellic acid on male sterility, seed yield and oil and fatty acid syntheses of safflower (Carthamus tinctorius L.). - Turkish Journal of Biology 24: 159-168.

[8] Baydar, H., Erbas, S. (2016): Line development breeding for high yield, oil and oleic acid content in safflower (Carthamus tinctorius L.). - Journal of Field Crops Central Research Institute 25(2): 155-161.

[9] Bilsborrow, P. E., Evans, E. J., Murray, F., Zhao, F. J. (1993): Glucosinolate changes in developing pods of single and double low varieties of autumn sown oilseed rape (Brassica napus L.). - Ann. App. Biol. 122: 135-143.

[10] Brittenham, G. M. (1994): New advances in iron metabolism, iron deficiency and iron overload. - Current Opinion in Hematology 1: 549-556.

[11] Burzo, I., Toma, S., Dobrescu, A., Ungurean, L., Stefan, V. (1999): Physiology of the growing plants, Volume II: Physiology of the field crops. - Enteprise for publishing Science Publishing House, pp. 180-207.

[12] Canellas, L. P., Olivares, F. L., Aguiar, N. O., Jones, D. L., Nebbioso, A., Mazzei, P., Piccolo, A. (2015): Humic and fulvic acids as biostimulants in horticulture. - Scientia Horticulturae 196: 15-27.

[13] Corleto, A., Alba, E., Polignano, G. B., Vonghia, G. (1997): Safflower: A multipurpose species with unexploited potential and world adaptability. The Research in Italy. - IV ${ }^{\text {th }}$ International Safflower Conference, (2-7 June), 23-31 Bari, Italy.

[14] Darinkaboud, B. A., Asl, S. G. (2016): The oil and protein content of Isfahahn's safflower seed in different periods of irrigation, levels of humic acid and superabsorbent. International Journal of Life Science Pharma Research 1 (Special Issue): 56-63.

[15] Ekin, Z. (2020): Co-application of humic acid and Bacillus strains enhances seed and oil yields by mediating nutrient acquisition of safflower plants in semi-arid region. - Applied Ecology And Environmental Research 18(1): 1883-1900.

[16] Emongor, V., Oagile, O. (2017): Safflower Production. - Published by: The Botswana University of Agriculture and Natural Resources Private Bag 0027 Gaborone, Botswana. 
[17] Esendal, E., Kevseroglu, K., Uslu, N., Aytac, S. (1992): The effect of spring and winter planting on yield and important characters of safflower. - University of Ondokuz Mayis, Faculty of Agriculture, Years of Research, Project No: Z-044, pp. 119-121.

[18] Esendal, E. (2001): Safflower production and research in Turkey. - $\mathrm{V}^{\text {th }}$ International Safflower Conference, Williston, North Dakota, Sidney, Montana, USA, July 23-27, pp. 203-206.

[19] Galavi, M., Ramroudi, M., Tavassoli, A. (2012): Effect of miconutrients foliar application on yield and seed oil content of safflower (Carthamus tinstorius L.). - African Journal of Agricultural Research 7(3): 482-486.

[20] Garcia, A. (2009): Insulin production from transgenic safflower. http://www.sembiosys.ca/.

[21] Gursoy, M., Kolsarici, O. (2017): The effects of different humic acid dose on the yield and yield components of summer rape (Brassica napus ssp. oleifera L.) under Ankara conditions. - KSU J. Nat. Sci. 20 (Special vol.): 186-191.

[22] Haghighati, A. (2010): Study on the effects of nitrogen and phosphorus fertilizers on the yield and oil content of safflower lines in drylands. - Research Journal of Agronomy 4(3): 57-62.

[23] Hussain, M. I., Dionyssia-Angeliki, L., Farooq, M., Nikoloudakis, N., Khalid, N. (2015): Salt and drought stresses in safflower: a review. - Agronomy for sustainable development 36: $1-31$.

[24] Icel, C. D. (2005): The effect of different application dates and doses of humic acids on yield, yield components and oil ratio of safflower (Carthamus tinctorius L.). - Ankara University Graduate School of Natural and Applied Sciences Department of Field Crops Master Thesis, 80p., Ankara, Turkey.

[25] Kaleem, S., Hassan, F. U., Farooq, M., Rasheed, M., Munir, A. (2010): Physio-morphic traits as influenced by seasonal variation in sunflower; A Review. - Int. J. Agric. Biol. 12: 468-473.

[26] Karimi, E., Tadayyon, A., Tadayyon, M. R. (2016): The effect of humic acid on some yield characteristics and leaf proline content of safflower under different irrigation regimes. - Journal of crops improvement (Journal of Agriculture) 18(3): 609-623.

[27] Korkmaz, K. (2000): Effects of application of iron and humic acid the soybean growth and micro element content. - Gaziosmanpaşa University Graduate School of Natural and Applied Science Department of Soil Science Master Thesis, 69p., Tokat, Turkey.

[28] Koutroubas, S. D., Papakosta, D. K., Doitsinis, A. (2009): Phenotypic variation in physiological determinants of yield in spring sown safflower under Mediterranean conditions. - Field Crops Research 112: 199-204.

[29] Lakzayi, M., Sabbagh, I. (2015): Influence of foliar application and variety on some characteristics of Safflower. - Trends in Life Sciences 4(4): 585-588.

[30] Lewis, D. C., McFarlane, J. D. (1986): Effect of foliar applied manganese on the growth of safflower (Carthamus tinctorius L.) and the diagnosis of manganese deficiency by plant tissue and seed analysis. - Aust. J. Agric. Res. 37: 567-572.

[31] Lobartini, J. C., Orioli, G. A., Tan, K. H. (1997): Characteristics of soil humic acid fractions seperated by ultrafiltration. - Com. Soil Sci. Plant Anal. 28: 787-796.

[32] Malan, C. (2015): Review: humic and fulvic acids. A Practical Approach. - In: Sustainable Soil Management Symposium, Stellenbosch, 5-6 November 2015, Agrilibrium Publisher.

[33] Marschner, H. (1995): Mineral nutrient of higher plants. - Second ed., Academic Press Limited, Harcourt Brace and Company, Publishers, London, pp. 347-364.

[34] Mehraban, A., Miri, M. (2017): Influence of humic acid and mycorrhiza on some characteristics of safflower (Carthamus tinctorius L.). - Journal of Research in Ecology 5(1): 508-514. 
[35] Moradi, P., Pasari, B., Fayyaz, F. (2017): The effects of fulvic acid application on seed and oil yield of safflower cultivars. - Journal of Central European Agriculture 18(3): 584597.

[36] Movahhedy-Dehnavy, M., Modarres-Sanavy, S. A. M., Mokhtassi-Bidgoli, A. (2009): Foliar application of zinc and manganese improves seed yield and quality of safflower (Carthamus tinctorius L.) grown under water deficit stress. - Ind. Crops Prod. 30: 82-92.

[37] Mustin, M. (1987): Le Compost: Gestion de LA Matiere organique. - Editions Francois Dubus C 35. Reu. Mathurin-Regnier 75015, Paris.

[38] Pande, P., Anwar, M., Chand, S., Yadav, V. K., Patra, D. D. (2007): Optimal level of iron and zinc in relation to its influence on herb yield and production of essential oil in menthol mint. - Communications in Soil Science and Plant Analysis 38(5-6): 561-578.

[39] Rahimi, A., Khoram, A., Biglarifard, A. (2016): Effect of using humic, foliar application of compost tea and wermiwash on yield and yield component of safflower (Carthamus tinctorius L.). - International Scientific Journal "Mechanization In Agriculture" 6: 22-24.

[40] Rashno, M. H., Tahmasebi Sarvestani, Z. A., Heidari Sharifabad, H., Modarres Sanavi, S., Tavakkol Afshari, R. (2013): The effect of drought stress and iron spraying on yield and quality of two alfalfa cultivars. - Iranian Journal of Crop Plants Production 1: 125148.

[41] Ravi, S., Channal, H. T., Hebsur, N. S., Patil, B. N., Dharmatti, P. R. (2008): Effect of sulphur, zinc and iron nutrition on growth, yield, nutrient uptake and quality of safflower (Carthamus tinctorius L.). - Karnataka J. Agric. Sci. 21: 382-385.

[42] Sahan, H. (2019): Effects of humic acid and potassium on quality and yield of safflower (Carthamus tinctorius L.). - Ordu University Institue of Science and Technology Field Crops Master Thesis, 43p., Ordu, Turkey.

[43] Said-Al Ahl, H., Omer, E. A. (2009): Effect of spraying with zinc and/or iron on growth and chemical composition of coriander (Coriandrum sativum L.) harvested at three stages of development. - J. Medicinal Food Plants 1(2): 30-46.

[44] Vaughan, D., Linehan, D. J. (1976): The growth of wheat plants in humic acid solutions under axenic conditions. - Plant Soil 44: 445-449.

[45] Weiss, E. A. (1983): Oilseed crops: Safflower. - Longman Group Limited, Longman House, London, UK, pp. 216-281.

[46] Weiss, E. A. (2000): Safflower. - In: Oilseed Crops, Blackwell Sci. Ltd., Victoria, Australia, pp. 93-129.

[47] Yilmaz, E., Alagoz, Z. (2001): The effects of humic acid application on aggregate formation and stability in soils. - II. Ecological Agriculture Syposium, 16 November 2001, Antalya, Turkey, pp. 134-143. 